
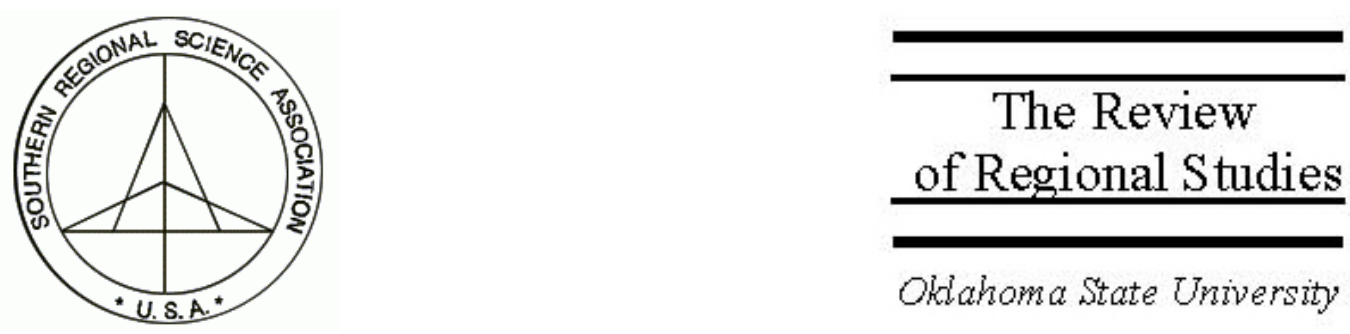

\title{
The Impact of Petroleum Product Prices on State Economic Conditions: An Analysis of the Economic Base
}

\author{
Christopher S. Decker \\ Department of Economics, College of Business Administration, University of Nebraska at \\ Omaha, Omaha, NE 68182-0048,e-mail: christopherdecker@mail.unomaha.edu
}

\section{Mark E. Wohar}

Department of Economics, College of Business Administration, University of Nebraska at Omaha, Omaha, NE 68182-0048,e-mail: mwohar@mail.unomaha.edu

\begin{abstract}
Recent energy price increases have revitalized interest in energy's impact on state economies. Moreover, lackluster economic growth in most states prompted some to suspend gas tax collections to stimulate economic activity. Given such interest, surprisingly few studies have quantified the effect energy has on state economies. Two questions are thus addressed here: 1) what is the impact of higher energy prices on state employment, and 2) what is the impact of a gas tax suspension. We find that the impact of increased petroleum-based energy prices on employment growth is small, calling into question the efficacy of a gas tax suspension.
\end{abstract}

Keywords: Petroleum prices; Employment growth

JEL classification: RO; Q4; H7 


\section{INTRODUCTION}

Recent sustained increases in world oil prices as well as the current political environment have revitalized interest among economists and policy analysts on the economic impact of rising energy costs on the U.S. economy. According to the U.S. Department of Energy's Energy Information Administration (EIA), since reaching a low of about $\$ 0.96$ per gallon in February 1999, average national retail gasoline prices increased to about $\$ 1.52$ per gallon as of mid-May 2003 and climbed further, averaging $\$ 2.03$ per gallon as recently as October, 2004. Indeed, there appears to be little reason to hope that this upward trend will reverse any time soon. Gasoline is not the only energy commodity experiencing substantial price increases. Residual fuel used by many electric utility and industrial plants, for instance, has increased from a recent low of $\$ 0.26$ per gallon in February 1999 to $\$ 0.77$ per gallon in September 2004. Indeed, even nonpetroleum energy prices (which tend to be highly correlated with petroleum-based energy prices) have climbed substantially in recent months. The wellhead price of natural gas, for instance, has increased from a recent low of $\$ 0.17$ per 1,000 cubic feet in March 1999 to a high of $\$ 0.59$ per 1,000 cubic feet in June 2004. As of September 2004, gas prices are still at a relatively high $\$ 0.48$ per 1,000 cubic feet. ${ }^{1}$

The reasons for these increases are subject to substantial debate. Irrespective of the cause, with the exception of a few brief periodic declines, these prices have nonetheless sustained their current historically high levels. Combined with recent terrorist activities, these price increases have renewed concerns over this country's dependence on foreign oil, resulting in heated debates over how best to overcome this dependence. While much of the debate has taken place at the national level (i.e., whether to promote alternative fuel technologies, open the Alaskan Wildlife Refuge to oil exploration and development, and so forth), there have been some state and local policy responses to increased energy prices.

Our interest here is not to attempt to answer why prices have, yet again, accelerated, but rather to empirically address the potential impact such price increases have on U.S. state economies, specifically with respect to employment growth. While a rich literature has investigated the link between economic growth and energy prices (reviewed below), most of these studies have focused their attention on national or international impacts. Relatively few have focused specific attention on state or regional economies, and those studies precede the current energy price acceleration that the U.S. is currently experiencing by a number of years.

Indeed, this recent run-up in energy prices came at a particularly difficult time for many U.S. states as the 2001-2003 economic slowdown generated significant revenue

\footnotetext{
${ }^{1}$ This data is available from the Energy Information Administration, U.S. Department of Energy, at www.eia.doe.gov.
} 
shortfalls for almost every state in the nation. To combat these short falls, some states have considered increases in gas taxes. ${ }^{2}$

However, given the recent economic slowdown experienced in many states, some state governors, rather than increasing state gas taxes, have instead attempted to stimulate their economies by suspending state gas tax collections. For instance, declaring an "energy emergency" in June of 2000, Indiana's late Governor Frank O'Bannon suspended that state's gasoline sales tax for a period of 60 days and later that summer extended the suspension an additional 15 days. While the midwestern states did indeed witness some of the largest increases in gasoline prices that summer and Indiana residents surely realized some relief at the gas pump as a result of this policy, the move was estimated to have cost the state between $\$ 22$ and $\$ 30$ million in lost revenue collections. ${ }^{3}$ After O'Bannon suspended the Indiana tax, Governor George Ryan of Illinois, observing Illinois residents crossing into Indiana to fill their gas tanks, followed suit and suspended that state's gas tax temporarily. ${ }^{4}$

The efficacy of such temporary tax suspension policies is itself subject to question. Opponents of such measures point to canceled or delayed road development or improvement projects resulting from lost state revenues. Such cancellations and delays can jeopardize road safety and construction jobs. Moreover, it is argued that lower gas prices resulting from the tax suspension will likely increase gasoline consumption, running counter to efforts to alleviate foreign oil dependence.

Proponents of such a policy can point to a large number of studies that have linked surges in oil prices to economic disruptions (see Stern 1993, for a review of this literature). For instance, Hamilton (1983) found that every recession in the U.S. save one was preceded by a substantial increase in oil prices. Stern (1993) also found that final energy use "Granger" caused GDP growth in the U.S. Presumably, then, energy prices should impact, to some degree, GDP growth. Moreover, using a Vector Autoregression model (VAR) to model the U.S. economy, Deravi and Hegji (1992) found that while increases in oil prices had a negligible effect on inflation, impulse response functions generated from a positive shock to world oil prices produced sizable, though transitory, reductions in real GDP growth. Therefore, it would seem that a policy aimed at reducing energy prices should have real effects on the economy.

Of course, the difficulty with relating the results of these studies to policies such as the one adopted by Indiana and Illinois is that the impact of energy prices on an economy will vary from region to region. For instance, energy producing states such as Texas and Wyoming might very well welcome higher energy prices since it would stimulate oil and

${ }^{2}$ Typically, most of the revenue generated from these taxes is directed towards transportation needs. See, for example, Aksamit (2002).

${ }^{3}$ See Indianapolis Star, 2000: "Governor Suspends Gas Tax," taken from Indystar.com at www. indystart.com, accessed on line by authors on June 2002.

${ }^{4}$ See Adhicary (2000). 
gas exploration and production. Moreover, energy prices themselves vary by region. According to the U.S. Department of Energy's EIA, in May of 2001 gasoline prices ranged from an average $\$ 1.47$ in Louisiana to nearly $\$ 2.00$ in California.

This being the case, three questions are addressed in this paper. The first two address the general impact higher petroleum-based product prices have on employment growth in a state. Specifically, we first ask which states will likely be the most adversely affected by higher prices. Second, we ask which states will benefit from these higher prices and to what degree? The third question is policy oriented. Specifically, building on the subsequent analysis, which states are likely to be the greatest beneficiaries of a temporary gas tax suspension? Our analysis suggests that while the effect varies from state to state, petroleum-based energy prices have a relatively small impact on state employment growth. Hence, the suspension of a gas tax will have a negligible impact on job growth, regardless of the state examined. This is the case even for those states that gain the most jobs relative to other states, calling into question the efficacy of such a policy.

This paper is organized as follows. In Section 2 we discuss the relevant regional economics literature on energy's role in determining state economic growth and discuss the state-level data employed in this study, highlighting for each state the energyintensive industries' contributions to the state's economic base growth. In Section 3 we present our basic empirical model and econometric results. In Section 4 we analyze and rank states in terms of their respective sensitivities to a general petroleum price decrease. In Section 5 we analyze the impact of a complete gas tax suspension and address some of the political and economic considerations of such a policy from the perspective of our estimates. In Section 6 we conclude.

\section{ENERGY, GROWTH, AND ECONOMIC BASE THEORY}

While empirical studies focusing on energy price impacts on the national economy abound, our review of the literature suggests that little attention has been paid to its impact on regional (state-level) economies. Moreover, there seems to be little consensus as to the significance of energy's impact on regional economies. For instance, investigating the economies of three energy-producing states, Hunt (1988) finds lower world oil prices reduce employment growth in Wyoming and Oklahoma by between 2 and 3 percent, while employment is only slightly increased in Colorado (presumably because Colorado has a more diverse industry mix in its economy). Hoag and Wheeler (1996) find that national oil price movements account for nearly 25 percent of the variance in mining employment in the state of Ohio. Finally, Bohi and Powers (1993) find that increases in national oil prices reduce employment and Gross State Product (GSP) growth in non-energy producing states, although the effect is very small. Contrary to these results, Munnell (1990), in a cross-sectional investigation of state employment growth over the periods 1970 to 1988,1970 to 1980 , and 1980 to 1988 for all states and industries, finds the cost of energy (dollars per million British Thermal Units, BTUs) is not consistently statistically significant. When it is, the estimated coefficient associated with the cost of energy has a positive effect on employment growth, running counter to the 
intuition, that at least in the short and medium run, energy and labor inputs are complements.

The study closest in spirit to ours is Brown and Hill (1988), who attempt to estimate the employment effects of world oil price reductions experienced between 1985 and 1988 (see also Brown and Hill 1995). As expected, they found that energy-producing states (Wyoming, Oklahoma, and so forth) are adversely affected by energy price declines. Conversely, those states that are comprised primarily of energy-consuming industries benefit, though statistical results obtained are not directly reported in their study.

Our analysis departs significantly from the aforementioned studies in a number of key respects. First, all of the existing work has investigated regional employment or income impacts of movements in national or world energy prices, primarily the world dollar price of crude oil per barrel. However, as illustrated by the Energy Information Administration data discussed above, this obscures the fact that energy prices can vary substantially from state to state. Hence, we focus attention on state-level petroleum prices as our energy price variable. Second, while many of the previous studies mentioned measure state economic performance by employment growth, for reasons given below we focus attention on employment growth for those industries within a given state that are considered "basic" industries.

\subsection{Economic Base Theory}

There are many different modeling structures that have been employed to measure regional economies. Among these are input-output models and computable general equilibrium models. Other regional models adopt a type of Keynesian structure as well. ${ }^{5}$ Finally, there is the so-called economic base theory.

While challenged many times in its rather lengthy existence, economic base theory remains one of the main theories of regional economic growth for at least three reasons, beyond its intuitive appeal. First, empirical support for the model remains reasonably strong; second, it is the central structure employed in almost every regional forecasting model today; and third, it's easy to implement relative to other models (Polzin 2001). The essence of the theory asserts that a regional economy consists of sectors that are exogenous (or "basic" sectors in that they define a regional economy's economic base) and sectors that are endogenous (i.e., "derivative" or "non-basic") to that economy. Exogenous sectors represent the specialized production of goods and services for a given region whose primary market lies outside regional boundaries, the sales from which inject income into the regional economy. Derivative industries are those that are dependent on the basic industries and whose purpose is to support the local economy.

\footnotetext{
${ }^{5}$ See Armstrong and Taylor (2000) for a good discussion of the various methodologies used in regional economic policy.
} 
Substantial empirical support for this model does exist. As Polzin (2001) finds, consistent with earlier studies, the primary determinant of a state's non-basic employment growth is growth in a state's basic industries. ${ }^{6}$ Therefore, an understanding of what variables explain basic industry employment growth is essential to understanding the impact such variables will (indirectly) have on a state's overall employment growth.

\subsection{Classification of Industries as Basic and Derivative}

To determine which industries in a state are basic, we adopt a procedure developed by the U.S. Bureau of Economic Analysis (BEA 1995). Their method takes into consideration both qualitative industry characteristics as well as statistical thresholds when classifying an industry as basic. Durable goods manufacturing, most nondurable goods manufacturing, agriculture, and some transportation sectors are generally viewed as servicing national (or even international) markets and are, therefore, classified as basic. For other sectors, determining if it's basic to a local economy depends on whether the calculated location quotient exceeds a certain pre-determined threshold level. ${ }^{7}$ Non-basic or derivative industries, by contrast, are simply those industries that primarily support a local economy's basic industries.

\subsection{Energy and the Base Economy}

As stated above, there is empirical support underscoring the importance of basic industry growth to the overall well-being of a state's economy. Polzin (2001), for instance, shows empirically that over the periods 1969 to 1977,1977 to 1985 , and 1985 to 1994 a state's derivative employment growth is strongly positively correlated with employment growth in a state's basic industries. Indeed, he finds little evidence to suggest that determinants other than basic industry growth, such as poverty rates, educational attainment and environmental conditions, consistently determine derivative employment growth.

With the economic base critical to the well-being of a state, the natural question to ask is what determines growth in the economic base. Because the market for a state's basic industries is national, the economic growth for the U.S. economy as a whole should, in theory, be the primary determinant of a state's economic base growth. However, many of the industries that comprise a state's economic base are "high energy content" industries, that is, those industries that are either large consumers of energy inputs or large

\footnotetext{
${ }^{6}$ These results extend beyond employment considerations. For instance, Polzin (2001) also shows that growth in basic industry income is also the primary determinant of non-basic industry income growth.

${ }^{7}$ By definition, a location quotient is the ratio of a state's employment share in a given industry to the same employment share for the country as a whole. For most industries, the threshold value for classifying an industry as basic is one. However, for some industries, the threshold value exceeds one. These thresholds are constructed by BEA and are largely the result of investigating historical trends in these series. We adopt the BEA thresholds in this study.
} 
generators of energy inputs (such as oil and natural gas extraction, petroleum refining, etc.). Hence, the cost of energy should impact the economic base of a state as well.

In classifying "high energy content industries," we utilized two sources. First, for manufacturing industries, we utilized the U.S. Department of Energy's EIA's 1998 report on fuel consumption ratios by industry for the U.S. as a whole. This ratio, calculated by EIA, measures a given industry's energy usage, measured in thousands of BTUs per dollar of total value added generated in that given industry. The fuel consumption ratio for total U.S. manufacturing was 9.4 BTUs per dollar of industrial value added. We classified those industries with ratios in excess of this average as "energy intensive." These industries are textiles, wood products, paper, petroleum and coal products, chemicals, nonmetallic mineral products (stone, clay, and glass) and primary metals (primary iron and steel manufacturing). ${ }^{8}$

Since the EIA report only included manufacturing industries, we consulted the BEA's 1998 "USE" table from their input-output matrix for the U.S. economy. This provided us with information on the inputs to each industry's total output. If an industry realized a significant amount of its total value from oil and gas production and/or petroleum refining, we considered it an energy intensive industry. This analysis revealed that coal mining, nonmetallic mineral mining, pipelines, air, water, railroad, trucking, and other service transportation sectors including local and interurban transportation (buses, taxis, etc.) should be added. Finally, we added oil and gas extraction itself to our list of energy intensive industries.

Columns 2 and 3 of Table 1 present each state's share of base employment that can be classified as energy intensive and the percentage contribution to base employment

\footnotetext{
${ }^{8} \mathrm{~A}$ few important points are required before continuing. First, these ratios measure total BTUs of "fuel" per dollar of value added. "Fuel" does include petroleum, natural gas, electricity, and other energy generating inputs and the EIA does not provide information on energy consumption for specific fuels. Hence, with the focus of this paper being petroleum prices, such a measure of energy intensity may over-inflate a petroleum price impact on these industries. While this is likely true, it should be kept in mind that there is a high correlation between petroleum prices and other energy prices such as natural gas and electricity. While any detailed causes may differ, with increases in petroleum prices there are likely to be increases in natural gas and electricity prices as well. Second, these ratios are based on national averages, not state averages, as the EIA does not report state averages for these ratios. However, the EIA does publish regional ratios, although for only four regions of the U.S. The use of national ratios, however, should generate very little bias for most industries as the variation around the national average is small. The largest variation (and this variation is substantially larger than other industries) comes from the petroleum products industry. The national average BTU ratio for this industry was about 120 per dollar of value added in 1998. In the western region of the U.S., this ratio was about 100 BTUs per dollar of value added (about 16 percent lower), and in the southern region this ratio was 160 BTUs per dollar of value added (about 30 percent higher). While for this market this variation is not trivial, the differences are likely not large enough to generate substantially different results.
} 
growth attributable to growth in energy intensive sectors. ${ }^{9}$ For example, energy employment's share of total base employment in Texas is 35 percent, and over the period 1970 to 1999, energy employment growth accounted for 37 percent of total base employment growth in Texas. The data suggests that the energy sector's impact on base growth is higher in energy producing states such as Wyoming, Louisiana, Texas, and Oklahoma. Moreover, we would expect energy base employment growth to be positively correlated with higher energy prices in such states. Likewise, we should expect a negative correlation between energy prices and energy employment growth in energy consuming states. Reviewing these correlations in column 4 of Table 1, this tends to be the case. West Virginia, North Carolina, South Carolina, Tennessee, Ohio, and Indiana, for instance, derive a reasonably large percentage of their respective economic base growth from energy intensive industries. These states tend to have a sizable amount of energy consuming industries such as chemical manufacturing and iron and steel manufacturing.

The foregoing analysis provides some indication of the relative importance of energy to a state's economy; however, it provides little insight into the effect that fluctuations in energy prices should have on the economy. This should depend on whether the state's base is primarily energy producing or primarily energy utilizing. We would expect energy prices to be positively correlated with the energy employment base in energy producing states because higher prices induce increased oil and gas exploration, mining, and development. ${ }^{10}$ Likewise, to the extent that, at least in the short run, energy and labor inputs are complements in production, states whose energy base is composed of energy consuming industries should see reductions in energy base employment growth resulting from increased energy prices.

To conduct our analysis, we obtained detailed state-level annual employment data by two-digit Standard Industrial Classification from the U.S. Bureau of Economic Analysis (BEA). ${ }^{11}$ Column 4 of Table 1 presents correlation coefficients between energy price movements and energy base employment growth over the period 1970 to 1999. Not surprisingly, there are strong negative correlations in heavy manufacturing states such as Alabama, Tennessee, Michigan, Iowa, and Indiana and strong positive correlations appear in oil and gas producing states such as Texas, Oklahoma, and Alaska.

\footnotetext{
${ }^{9}$ Employment shares measure the ratio of the average employment in energy intensive sectors to the average of base employment over the period 1970 to 1999. The energy sector's share of base employment growth, $B A S E$, was found by regressing over the period 1970 to 1999 for each state, $s, \ln \left(B A S E_{s, t} / B A S E_{s, t-1}\right)=\beta_{E} * \ln \left(E B A S E_{s, t} / E B A S E_{s, t-1}\right)+\beta_{N E} * \ln \left(N E B A S E_{s, t} / N E B A S E_{s, t-1}\right)$, where $E B A S E_{s, t}$ is energy intensive sector employment and $N E B A S E_{s, t}$ is non-energy intensive sector employment. The estimated $\beta_{E}$ is reported as energy's share of total base employment.

${ }^{10} \mathrm{We}$ might expect a positive correlation between energy prices and petroleum refining activities as well, however the effect may be mitigated. While higher crude oil prices might represent increased cost of inputs to refinery activity, the final products sold will fetch a higher price in the market. Given relatively inelastic demand (in the short run) for gasoline and home heating oils, etc., the net effect of higher energy prices for states whose energy base is largely petroleum refining might be positive.

${ }^{11}$ This data can be obtained at www.bea.gov/bea/regional/data.htm.
} 
TABLE 1

Energy Employment's Share of Base Economic Growth

\begin{tabular}{|c|c|c|c|c|}
\hline State & $\begin{array}{l}\text { Energy's Share of } \\
\text { Base Employment }\end{array}$ & $\begin{array}{l}\text { Energy's Share of } \\
\text { Base Growth }\end{array}$ & $\begin{array}{l}\text { EBASE Corr. } \\
\text { with Petprice }\end{array}$ & Category \\
\hline $\mathrm{AK}$ & 0.27 & 0.22 & 0.35 & 6 \\
\hline $\mathrm{AL}$ & 0.35 & 0.35 & -0.48 & 1 \\
\hline $\mathrm{AR}$ & 0.31 & 0.29 & -0.31 & 2 \\
\hline $\mathrm{AZ}$ & 0.12 & 0.12 & -0.29 & 2 \\
\hline $\mathrm{CA}$ & 0.06 & 0.07 & -0.09 & 4 \\
\hline $\mathrm{CO}$ & 0.07 & 0.10 & 0.22 & 6 \\
\hline $\mathrm{CT}$ & 0.10 & 0.10 & -0.11 & 3 \\
\hline $\mathrm{DE}$ & 0.27 & 0.31 & 0.08 & 5 \\
\hline FL & 0.04 & 0.05 & -0.08 & 4 \\
\hline $\mathrm{A}$ & 0.25 & 0.26 & -0.29 & 2 \\
\hline $\mathrm{HI}$ & 0.13 & 0.11 & -0.09 & 4 \\
\hline IA & 0.19 & 0.19 & -0.44 & 1 \\
\hline ID & 0.26 & 0.27 & -0.29 & 2 \\
\hline IL & 0.15 & 0.14 & -0.30 & 2 \\
\hline $\mathrm{IN}$ & 0.31 & 0.31 & -0.43 & 1 \\
\hline $\mathrm{KS}$ & 0.24 & 0.26 & 0.26 & 6 \\
\hline KY & 0.33 & 0.31 & -0.30 & 2 \\
\hline LA & 0.47 & 0.50 & 0.14 & 6 \\
\hline MA & 0.06 & 0.09 & -0.11 & 3 \\
\hline MD & 0.06 & 0.07 & -0.15 & 3 \\
\hline $\mathrm{ME}$ & 0.15 & 0.19 & -0.06 & 4 \\
\hline MI & 0.16 & 0.17 & -0.45 & 1 \\
\hline $\mathrm{MN}$ & 0.21 & 0.20 & -0.29 & 2 \\
\hline MO & 0.20 & 0.20 & -0.32 & 2 \\
\hline MS & 0.28 & 0.26 & -0.19 & 3 \\
\hline MT & 0.17 & 0.20 & -0.22 & 2 \\
\hline $\mathrm{NC}$ & 0.39 & 0.39 & -0.28 & 2 \\
\hline ND & 0.19 & 0.18 & 0.27 & 6 \\
\hline $\mathrm{NE}$ & 0.16 & 0.16 & -0.06 & 4 \\
\hline $\mathrm{NH}$ & 0.08 & 0.10 & 0.03 & 5 \\
\hline $\mathrm{NJ}$ & 0.20 & 0.23 & -0.07 & 4 \\
\hline NM & 0.24 & 0.24 & -0.03 & 4 \\
\hline NV & 0.14 & 0.17 & 0.00 & 5 \\
\hline NY & 0.07 & 0.10 & -0.13 & 3 \\
\hline $\mathrm{OH}$ & 0.32 & 0.32 & -0.42 & 1 \\
\hline OK & 0.30 & 0.35 & 0.50 & 6 \\
\hline OR & 0.27 & 0.34 & -0.43 & 1 \\
\hline PA & 0.20 & 0.24 & -0.43 & 1 \\
\hline RI & 0.11 & 0.11 & 0.02 & 5 \\
\hline $\mathrm{SC}$ & 0.41 & 0.44 & -0.30 & 2 \\
\hline
\end{tabular}




\begin{tabular}{ccccc}
\hline State & $\begin{array}{c}\text { Energy's Share of } \\
\text { Base Employment }\end{array}$ & $\begin{array}{c}\text { Energy's Share of } \\
\text { Base Growth }\end{array}$ & $\begin{array}{c}\text { EBASE Corr. } \\
\text { with Petprice }\end{array}$ & Category \\
\hline SD & 0.14 & 0.13 & -0.31 & 2 \\
TN & 0.34 & 0.34 & -0.45 & 1 \\
TX & 0.35 & 0.37 & 0.38 & 6 \\
UT & 0.29 & 0.29 & -0.31 & 2 \\
VA & 0.18 & 0.20 & -0.12 & 3 \\
VT & 0.14 & 0.13 & 0.18 & 6 \\
WA & 0.22 & 0.26 & -0.15 & 3 \\
WI & 0.26 & 0.23 & -0.31 & 2 \\
WV & 0.63 & 0.68 & -0.43 & 1 \\
WY & 0.45 & 0.51 & 0.18 & 6 \\
\hline
\end{tabular}

\section{ECONOMETRIC ANALYSIS}

Ideally, it would be preferable to estimate an equation for each state relating energyintensive economic base growth to energy prices, providing us with state-unique energy price effects on economic growth. However, consistent state-level data on energy prices and employment are very limited in the time dimension. State-level energy price data is, to our knowledge, only available from the U.S. Energy Information Administration and only as far back as 1970. Once the independent variables are introduced into the specification, degrees of freedom become severely limited, making statistical inference unreliable. Therefore, we proceed by creating different panels comprising groups of states with similar characteristics. Specifically, to measure regional price impacts on state employment growth, we have grouped states into six different categories based on the empirically observed correlations between petroleum product prices and energyintensive employment growth as reported in Table 1. The reason for generating groups based on these correlation measures is largely an effort to preserve to the best degree possible what the estimated impact of petroleum prices on employment growth would likely be if one had sufficient data to have estimated an equation for each state. ${ }^{12}$ Since

\footnotetext{
${ }^{12}$ To be sure, other measures could have been used to group states with similar energy-intensive characteristics. A natural alternative would have been to group states based on, say, the degree of aggregate energy input levels. That is, group together states with larger amounts of energy inputs and group states with lower levels of energy inputs together. We did, in fact, try this and for the most part, the resulting ranking and grouping of states was similar to the results presented here. However, this alternative grouping is potentially troubling. For instance, it is quite possible that, say, two or more states appear to have roughly similar levels of energy use but the efficiency with which these inputs are used varies. Perhaps in some states, the capital used in production is more advanced and energy efficient. Such states, while being energy intensive, may thus be largely insulated from petroleum price changes relative to similar energy intensive states where energy use is less efficient. A grouping based on correlations would pick up such differences in energy efficiency across states and, therefore, we opted for that construction.
} 
sufficient data was not available for each state, we thus created six different panel data sets that we use to conduct our econometric analysis. ${ }^{13}$

Category 1 states have correlations (between the growth in energy prices and energy base employment growth) less than -0.40 , category 2 between -0.40 and -0.20 , category 3 between -0.10 and -0.20 , category 4 between 0.00 and -0.10 , category 5 between 0.00 and 0.10 , and finally, category 6 between 0.10 and higher. ${ }^{14}$ Table 1 reports each state's categorical designation.

Six separate equations were estimated using both standard fixed-effects and randomeffects OLS over the period 1970 to 1999 . In this paper, we formally model energy base employment growth as a function of a measure of energy prices and national economic growth. The regression equation is given as:

$$
\begin{gathered}
\log \left(\text { EBASE }_{s, t} / \text { EBASE }_{s, t-1}\right) * 100=\alpha_{s}+\beta_{P} * \log \left(P P_{s, t} / P G D P_{t}\right)+ \\
\beta_{G} * \log \left(G D P 96_{t-1} / G D P 96_{t-2}\right) * 100+ \\
\beta_{E} * \log \left(E_{\text {EBASE }} / \text { EBASE }_{s, t-2}\right) * 100+e_{s, t} .
\end{gathered}
$$

$E B A S E_{s, t}$ represents (for each state) employment in energy intensive industries within a state's economic base, as stated earlier, using BEA data. The variable $P P_{s, t}$ is each state's average composite price for petroleum products as published by the EIA. ${ }^{15}$ We used this

\footnotetext{
${ }^{13} \mathrm{We}$ did, however, estimate 50 different regression equations, one for each state. Again, we feel that given the small sample size, the results are not reliable enough to present here (though these results are available upon request). However, it is important to note that the resulting coefficients (elasticities) on the petroleum price variable for each state are similar in magnitude to the petroleum price coefficient for each category where a given state is located. For instance, for the category 1 states, each estimated price elasticity resulting from the separate state regressions fell within the -5.7 and -10 percent range.

${ }^{14}$ These "breaks" in the correlations come largely from ordering all states based on the above correlation and identifying groups where there appeared to be relatively large differences in correlations from one state to the next while still leaving us with enough states in each group to provide reasonably reliable statistical results. We did not wish to have a group with fewer than six states. For instance, Indiana, Oregon, West Virginia, and Pennsylvania are all in category 1 with a petroleum price to employment growth correlation of -.43. The next state in order of correlation magnitude is Ohio with a correlation of -.42. The very next state in order of correlation magnitude is Missouri with a correlation -.32. We concluded then that Ohio is more like Indiana, etc., and less like Missouri and thus placed Ohio in category 1 and Missouri in category 2.

15 This data can be obtained at www.eia.doe.gov/emeu/states/_price_multistate.html. This composite price is constructed by EIA as a weighted average of a number of petroleum products prices. Products include distillate fuel, jet fuel, liquefied petroleum gasses, residual fuel, and motor gasoline. The weights are based largely on each fuel's share of total petroleum expenditures, the largest of which is motor gasoline. Hence, there is a very high correlation between this composite petroleum price used here and the price of motor gasoline. Indeed, for 40 of the 50 states, this price correlation is in excess of 98 percent over the period 1970 to 1999 . The lowest correlation is Alaska's, where the price correlation is 96 percent.
} 
broader price measure because we are ultimately interested in the impact that energy prices have on employment growth. This price measure, as stated above, is correlated with both other energy prices, natural gas prices for instance, as well as more specific petroleum-based fuels such as gasoline. For lack of a state-level measure of general inflation, the petroleum price is deflated by the national implicit price deflator, $P G D P_{t}$. We would expect that the cost of energy, as measured by $P P_{s, t}$ should have a negative impact on $E B A S E_{s, t}$ growth if $E B A S E_{s, t}$ is primarily comprised of energy consuming industries. By contrast, we would expect a positive impact on $E B A S E_{s, t}$ growth if $E B A S E_{s, t}$ is comprised primarily of energy producing industries. GDP96 ${ }_{t}$ is national gross domestic product (in 1996 dollars). ${ }^{16}$ Because the market for a state's basic industries is national, the economic growth for the U.S. economy as a whole should have a positive impact on a state's energy intensive employment base growth. Lagged $E B A S E_{s, t}$ growth is included largely as a control variable, testing whether there is any persistence in growth over time. The results of each panel regression are presented in Table $2 .{ }^{17}$

\section{PETROLEUM PRICES AND THE IMPACT ON ENERGY BASE EMPLOYMENT}

\subsection{Price Impact on Energy Base Employment Growth as a Whole}

Focusing attention on the price effect, the resulting elasticities are negative for categories 1,2, and 3 for both the fixed and random effects models; and the price effect is strongly significant in categories 1 and $2 .{ }^{18}$ Moreover, the magnitudes are roughly similar for both the fixed effect and random effect models. For the category 1 states, a 1 percent increase in the real price of petroleum products leads to an 8 percent decline in employment growth in energy intensive industries. For category 2 states, the resulting elasticity is about -4.7 percent. The price elasticity for category 3 states is about -1.0 percent but the effect is statistically insignificant.

For categories 4,5 , and 6 , the petroleum price effect is positive. However, real petroleum prices are only statistically meaningful for category 6 states. Within this category, comprised principally of energy producing states, we find that a 1 percent increase in the real price of petroleum products increases employment growth in energy intensive industries by 4 to 5 percent. For category 4 and 5 states, the price elasticities are positive but small ( 0.2 and 0.92 percent, respectively) and statistically insignificant.

\footnotetext{
16 This data can be obtained at www.bea.gov/bea/dn/home/gdp.htm.

${ }^{17}$ To conserve space, the state intercept coefficients have been omitted from this table. However, complete results of all panel regressions are available from the authors upon request.

${ }^{18}$ The test here is based on a two-tailed test of significance since the resulting coefficient on price can in theory be either positive or negative depending on the relative size and importance of energy consuming versus energy producing employment sectors in a given state.
} 
TABLE 2

Regression Results

\begin{tabular}{|c|c|c|c|c|}
\hline & \multicolumn{2}{|c|}{ Fixed Effects } & \multicolumn{2}{|c|}{ Random Effects } \\
\hline & Coefficient & t-statistic & Coefficient & t-statistic \\
\hline \multicolumn{5}{|c|}{ Category 1 (AL TN MI IA IN OR PA WV OH) } \\
\hline $\log \left(P P_{s, t} / P G D P_{t}\right)$ & -8.094 & $-6.873^{* * *}$ & -8.008 & $-7.996^{* * *}$ \\
\hline $\log \left(G D P 96_{t-1} / G D P 96_{t-2}\right)$ & 0.803 & $4.963^{* * *}$ & 0.785 & $6.516^{* * *}$ \\
\hline $\log \left(E B A S E_{s, t-1} / E B A S E_{s, t-2}\right)$ & -0.296 & $-2.609^{* * *}$ & -0.278 & $-4.268^{* * *}$ \\
\hline Adjusted $\mathrm{R}^{2}$ & 0.330 & & 0.254 & \\
\hline LM (3 d.f.) & 33.690 & & & \\
\hline Hausman test (3 d.f.) & -0.150 & & & \\
\hline \multicolumn{5}{|c|}{ Category 2 (MO SD WI UT AR IL KY SC AZ GA ID MN NC) } \\
\hline $\log \left(P P_{s, t} / P G D P_{t}\right)$ & -4.784 & $-4.748^{* * *}$ & -4.729 & $-5.101^{* * *}$ \\
\hline $\log \left(G D P 96_{t-1} / G D P 96_{t-2}\right)$ & 0.670 & $4.748^{* * *}$ & 0.641 & $5.736^{* * *}$ \\
\hline $\log \left(E B A S E_{s, t-1} / E B A S E_{s, t-2}\right)$ & -0.172 & $-2.085^{* *}$ & -0.143 & $-2.530^{* *}$ \\
\hline Adjusted $\mathrm{R}^{2}$ & 0.174 & & 0.141 & \\
\hline LM (3 d.f.) & $7.330^{* * *}$ & & & \\
\hline Hausman test ( 3 d.f.) & 0.020 & & & \\
\hline \multicolumn{5}{|c|}{ Category 3 (MT MS MD WA NY VA MA CT) } \\
\hline $\log \left(P P_{s, t} / P G D P_{t}\right)$ & -1.097 & -1.165 & -1.144 & -1.159 \\
\hline $\log \left(G D P 96_{t-1} / G D P 96_{t-2}\right)$ & 0.884 & $6.163^{* * *}$ & 0.864 & $6.551^{* * *}$ \\
\hline $\log \left(E B A S E_{s, t-1} / E B A S E_{s, t-2}\right)$ & -0.349 & $-4.089^{* * *}$ & -0.329 & $-4.477^{* * *}$ \\
\hline Adjusted $\mathrm{R}^{2}$ & 0.218 & & 0.133 & \\
\hline LM (3 d.f.) & $27.200^{* * *}$ & & & \\
\hline Hausman test ( 3 d.f.) & 0.020 & & & \\
\hline \multicolumn{5}{|c|}{ Category 4 (CA HI FL NJ ME NE NM) } \\
\hline $\log \left(P P_{s, t} / P G D P_{t}\right)$ & 0.225 & 0.140 & 0.036 & 0.020 \\
\hline $\log \left(G D P 96_{t-1} / G D P 96_{t-2}\right)$ & 1.011 & $4.630^{* * *}$ & 1.003 & $4.692^{* * *}$ \\
\hline $\log \left(E B A S E_{s, t-1} / E B A S E_{s, t-2}\right)$ & -0.495 & $-2.592^{* *}$ & -0.486 & $-7.821^{* * *}$ \\
\hline Adjusted $\mathrm{R}^{2}$ & 0.264 & & 0.238 & \\
\hline LM (3 d.f.) & $4.770^{* *}$ & & & \\
\hline Hausman test ( 3 d.f.) & -0.150 & & & \\
\hline \multicolumn{5}{|c|}{ Category 5 (NV RI NH DE VT) } \\
\hline $\log \left(P P_{s, t} / P G D P_{t}\right)$ & 0.919 & 0.510 & 0.890 & 0.375 \\
\hline $\log \left(G D P 96_{t-1} / G D P 96_{t-2}\right)$ & 0.712 & $2.809^{* * *}$ & 0.695 & $2.442^{* *}$ \\
\hline $\log \left(E B A S E_{s, t-1} / E B A S E_{s, t-2}\right)$ & -0.015 & -0.143 & -0.002 & -0.021 \\
\hline Adjusted $\mathrm{R}^{2}$ & 0.125 & & 0.063 & \\
\hline LM (3 d.f.) & $8.350^{* *}$ & & & \\
\hline Hausman test (3 d.f.) & -0.100 & & & \\
\hline \multicolumn{5}{|c|}{ Category 6 (WY LA CO KS ND AK TX OK) } \\
\hline $\log \left(P P_{s, t} / P G D P_{t}\right)$ & 5.293 & $1.950^{*}$ & 4.296 & $2.371^{* *}$ \\
\hline $\log \left(G D P 96_{t-1} / G D P 96_{t-2}\right)$ & 0.523 & $2.783^{* * *}$ & 0.511 & $2.605^{* * *}$ \\
\hline $\log \left(\operatorname{EBASE}_{s, t-1} / \mathrm{EBASE}_{s, t-2}\right)$ & 0.268 & $2.854^{* * *}$ & 0.299 & $4.599^{* * *}$ \\
\hline Adjusted $\mathrm{R}^{2}$ & 0.138 & & 0.153 & \\
\hline LM (3 d.f.) & 0.410 & & & \\
\hline Hausman test (3 d.f.) & -0.100 & & & \\
\hline
\end{tabular}


These results highlight the potential benefits and costs of lower petroleum product prices in some states as well as providing some information on when changes in such prices are not likely to have a meaningful impact on a given state's employment base. Given the above estimated elasticities, it is possible to estimate the number of jobs saved when a state suspends its gasoline tax collections, giving an indication of the efficacy of such a policy.

Before continuing, as we consider using our basic analysis to address the potential impact of such a tax suspension, a few important points need to be addressed. First, our selection of the composite petroleum price was largely driven by one of our motivations for this paper, that is, to measure general changes in petroleum-based energy prices' impact on state employment growth. (Such effects involve many different energy uses, from motor fuel to petroleum coke and residual fuel used in commercial and industrial production.) Hence, our elasticities are not specific to motor fuel prices, as would be desirable in analyzing the impact of a gas tax suspension. However, if petroleum-based inputs to industrial production are necessary inputs in the short term or if production primarily uses some other type of energy input, one might reasonably expect that the employment elasticity with respect to non-gasoline uses to be smaller than the corresponding elasticity for gasoline. ${ }^{19}$ As such, our estimates using elasticities obtained from the broader price measure may be biased upwards and, as a result, the number of jobs potentially saved from a gas tax suspension can be considered an "upper threshold" employment impact. From this perspective, we can think then of giving the policy maker proposing such a gas tax suspension the benefit of the doubt, as it were, that there will be some employment impact. The question is, maximally, how much.

Second, because we estimated our elasticities using annual data over a 29-year period, the resulting elasticities might reasonably be considered as having "long-run" characteristics. For the type of policy scenario being considered here, short-run elasticities would be preferable. Unfortunately, higher frequency data on detailed industrial employment and detailed energy prices at the state level is unavailable. However, it is likely that the short-run elasticities would be smaller in magnitude to the ones estimated here. As a result, any employment effects will likely be smaller, and thus, an analysis using our estimated elasticities would overstate the impacts of a gas tax suspension. Therefore, we can think of the resulting impact numbers as giving a reasonable upper bound as to the efficacy of such a suspension.

Third, it seems fairly clear that those states that benefit from lower petroleum prices will in turn realize some economic gain from a gas tax suspension. However, to then assert that those states that suffer from lower petroleum prices would be adversely affected by a gas tax suspension would be fallacious. Even though energy-producing

\footnotetext{
${ }^{19}$ For instance, if production in Louisiana uses primarily natural gas or coal, then suspending that state's gas tax will unlikely result in much increase in employment. We thank an anonymous referee for this insight.
} 
states such as Alaska, Texas, and Oklahoma benefit overall from higher prices for the products they manufacture, surely residents in those states would welcome gas tax relief. In turn, such relief would likely stimulate quantity demanded for petroleum products that would in turn benefit suppliers in those states. Hence, while our results suggest that lower petroleum prices are detrimental to the economic base for some states, we should not conclude that higher taxes are necessarily warranted.

\subsection{Price Impact on Energy Consuming Base Employment Growth}

This third point is critical to our foregoing analysis. Indeed, since it is highly likely that the own price elasticity of demand for petroleum inputs in the short run is very small and therefore it is the consumers of these products who will bear the greatest burden of the tax, it is difficult to imagine how a reduction in the gas tax would affect energy-producing sectors. Moreover, it is possible that these energy consuming sectors will likely have different responses, both in sign and magnitude, to changes in petroleum prices than energy producing sectors. Hence, for the express purpose of obtaining some reasonable measure of an employment impact from a reduction in petroleum prices from, for example, a gas tax suspension, we re-estimated equation (1) removing from EBASE those sectors that are generally considered to be, for the most part, net energy producing industries: coal mining, oil and gas extraction, and petroleum and coal refining industries. With this resulting energy consuming employment measure, EBASEC, we re-estimated the following equation:

$$
\begin{gathered}
\log \left(\text { EBASEC }_{s, t} / \text { EBASEC }_{s, t-1}\right) * 100=\alpha_{s}+\beta_{P} * \log \left(P P_{s, t} / P G D P_{t}\right)+ \\
\beta_{G} * \log \left(G D P 96_{t-1} / G D P 96_{t-2}\right) * 100+ \\
\beta_{E} * \log \left(\text { EBASEC }_{s, t-1} / \text { EBASEC }_{s, t-2}\right) * 100+e_{s, t} .
\end{gathered}
$$

These results are presented in Table $3 .^{20}$ Again, both fixed and random effects models were estimated, and while the Hausman test statistics seems to favor the fixed effects model for categories 1,2, and 3 only, in each of the subsequent categories the estimated elasticities on $P P_{s, t}$ are similar across econometric models.

When comparing these results to those presented in Table 2, we find results consistent with expectation. First, we note that when only energy consumption employment growth is considered, the estimated elasticity of $P P_{s, t}$ on such growth is negative and

\footnotetext{
${ }^{20}$ We did not re-rank and re-group states when conducting this analysis. For the U.S., in 1999, energy consuming employment's share of the total energy base was roughly 90 percent. Since there were only a few states, Oklahoma, Texas, Wyoming, and Alaska, where this percentage was substantially lower, and since these states were already in group 6 to begin with, a re-ranking using EBASEC (as we did try) resulted in very little change in our original groupings. Moreover, since we focus in this section on the energy consumption sector, we've omitted presenting the econometric results for the energy producing sectors. These regression results are available upon request from the authors. Moreover, readers interested in the price impact on employment in energy producing states are referred to Hunt (1988).
} 
TABLE 3

Regression Results: Energy Consuming Industries

\begin{tabular}{|c|c|c|c|c|}
\hline & \multicolumn{2}{|c|}{ Fixed Effects } & \multicolumn{2}{|c|}{ Random Effects } \\
\hline & Coefficient & t-statistic & Coefficient & t-statistic \\
\hline \multicolumn{5}{|c|}{ Category 1 (AL TN MI IA IN OR PA WV OH) } \\
\hline $\log \left(P P_{s, t} / P G D P_{t}\right)$ & -9.232 & $-9.316^{* * *}$ & -8.577 & $-8.766^{* * *}$ \\
\hline $\log \left(G D P 96_{t-1} / G D P 96_{t-2}\right)$ & 0.864 & $7.083^{\text {*** }}$ & 0.733 & $6.111^{* * *}$ \\
\hline $\log \left(E B A S E C_{s, t-1} / E B A S E C_{s, t-2}\right)$ & -0.347 & $-5.162 * * *$ & -0.226 & $-3.512^{* * *}$ \\
\hline Adjusted $\mathrm{R}^{2}$ & 0.368 & & 0.287 & \\
\hline LM (3 d.f.) & $40.490^{* * *}$ & & & \\
\hline Hausman test ( 3 d.f.) & $38.720^{* * *}$ & & & \\
\hline \multicolumn{5}{|c|}{ Category 2 (MO SD WI UT AR IL KY SC AZ GA ID MN NC) } \\
\hline $\log \left(P P_{s, t} / P G D P_{t}\right)$ & -5.816 & $-6.403^{* * *}$ & -5.749 & $-6.344^{* * *}$ \\
\hline $\log \left(G D P 96_{t-1} / G D P 96_{t-2}\right)$ & 0.732 & $6.381^{* * *}$ & 0.700 & $6.125^{* * *}$ \\
\hline $\log \left(E B A S E C_{s, t-1} / E B A S E C_{s, t-2}\right)$ & -0.218 & $-3.728^{* * *}$ & -0.189 & $-3.274^{* * *}$ \\
\hline Adjusted $\mathrm{R}^{2}$ & 0.214 & & 0.169 & \\
\hline LM (3 d.f.) & $13.810^{* * *}$ & & & \\
\hline Hausman test (3 d.f.) & $10.260^{* *}$ & & & \\
\hline \multicolumn{5}{|c|}{ Category 3 (MT MS MD WA NY VA MA CT) } \\
\hline $\log \left(P P_{s, t} / P G D P_{t}\right)$ & -2.140 & $-2.217^{* *}$ & -2.159 & $-2.242^{* *}$ \\
\hline $\log \left(G D P 96_{t-1} / G D P 96_{t-2}\right)$ & 0.895 & $6.843^{* * *}$ & 0.878 & $6.724^{* * *}$ \\
\hline $\log \left(E B A S E C_{s, t-1} / E B A S E C_{s, t-2}\right)$ & -0.352 & $-4.842^{* * *}$ & -0.336 & $-4.641^{* * *}$ \\
\hline Adjusted $\mathrm{R}^{2}$ & 0.240 & & 0.151 & \\
\hline LM (3 d.f.) & $32.600^{* * *}$ & & & \\
\hline Hausman test ( 3 d.f.) & 4.700 & & & \\
\hline \multicolumn{5}{|c|}{ Category 4 (CA HI FL NJ ME NE NM) } \\
\hline $\log \left(P P_{s, t} / P G D P_{t}\right)$ & -1.581 & $-1.301^{*}$ & & \\
\hline $\log \left(G D P 96_{t-1} / G D P 96_{t-2}\right)$ & 0.701 & $4.489^{* * *}$ & 0.682 & $4.380^{* * *}$ \\
\hline $\log \left(\right.$ EBASEC $_{s, t-1} /$ EBASEC $\left._{s, t-2}\right)$ & -0.157 & $-2.041^{* *}$ & -0.138 & $-1.814^{* *}$ \\
\hline Adjusted $\mathrm{R}^{2}$ & 0.141 & & 0.094 & \\
\hline LM (3 d.f.) & $8.130^{* * *}$ & & & \\
\hline Hausman test ( 3 d.f.) & 3.580 & & & \\
\hline \multicolumn{5}{|c|}{ Category 5 (NV RI NH DE VT) } \\
\hline $\log \left(P P_{s, t} / P G D P_{t}\right)$ & -1.291 & $-1.333^{*}$ & -1.329 & $-1.251^{*}$ \\
\hline $\log \left(G D P 96_{t-1} / G D P 96_{t-2}\right)$ & 0.572 & $2.124^{* *}$ & 0.472 & $1.612^{*}$ \\
\hline $\log \left(E B A S E C_{s, t-1} / E B A S E C_{s, t-2}\right)$ & -0.029 & -0.429 & 0.066 & 0.675 \\
\hline Adjusted $\mathrm{R}^{2}$ & 0.061 & & 0.027 & \\
\hline LM (3 d.f.) & $3.680^{*}$ & & & \\
\hline Hausman test (3 d.f.) & 1.030 & & & \\
\hline \multicolumn{5}{|c|}{ Category 6 (WY LA CO KS ND AK TX OK) } \\
\hline $\log \left(P P_{s, t} / P G D P_{t}\right)$ & -1.843 & $-1.360^{*}$ & -1.695 & $-1.320^{*}$ \\
\hline $\log \left(G D P 96_{t-1} / G D P 96_{t-2}\right)$ & 0.341 & $2.326^{* *}$ & 0.336 & $2.292^{* *}$ \\
\hline $\log \left(E B A S E C_{s, t-1} / E B A S E C_{s, t-2}\right)$ & 0.188 & $2.833^{* * *}$ & 0.207 & $3.165^{* * *}$ \\
\hline Adjusted $\mathrm{R}^{2}$ & 0.076 & & 0.089 & \\
\hline LM (3 d.f.) & 0.160 & & & \\
\hline Hausman test ( 3 d.f.) & 3.950 & & & \\
\hline
\end{tabular}


significant at the 10 percent level or better in every category. ${ }^{21}$ Second, as expected, the estimated petroleum price elasticities for categories 1,2, and 3 are generally larger in magnitude when only energy consumption sectors are considered. For instance, for the category 1 states, a 1 percent increase in the real price of petroleum products leads to a 9.2 percent decline in employment growth in energy consuming industries. Moreover, for the category 2 states, the resulting elasticity is about -5.8 percent.

\subsection{The Petroleum Price Impact on the Level of Employment}

Before discussing the specific quantitative effects of a gas tax suspension, we first utilize the elasticities from Table 3 to estimate the number of jobs saved from a 10 percent across the board decrease in petroleum prices. This is done in order to isolate the impact of a general price reduction. Later, when we analyze the impact of a gas tax suspension, the resulting employment effects will involve reducing per gallon tax collections to zero; and since state gas tax rates vary substantially both in level and percentage terms, one cannot in general obtain a measure of an expected employment increase from a price reduction that is directly comparable across states.

Table 4 reports the impact on energy consuming sector employment that would have been realized in the year 2000 if petroleum prices fell by 10 percent that year. According to our model, Ohio would have benefited the most from such as drop, saving some 3,692 jobs, followed by Pennsylvania, which would have retained 3,588 jobs on the payroll. Tennessee, Indiana, North Carolina, and Alabama would have also benefited greatly from a price drop, each saving 2,000 jobs or more. These results are roughly consistent with expectation since most of these states have substantial industrial sectors that consume a significant amount of petroleum based energy in production. States that would have realized the smallest gain in employment are Wyoming, New Mexico, New Hampshire, Rhode Island, and Vermont, all of which have relatively small energy consuming employment sectors to begin with.

In terms of jobs saved as percent of a state's total energy consuming employment base, we see that the impact of a 10 percent price drop is relatively small. The jobs saved in Ohio and Pennsylvania, the two states benefiting the most from a price drop, amount to less that 1 percent of the total base. While more detailed analysis is warranted, these results strongly suggest that little should be expected in jobs saved from a gas tax suspension, thus reducing the potential efficacy of such a policy.

${ }^{21}$ The test here is based on a one-tailed test of significance since when only energy consuming markets are taken into consideration, the resulting coefficient on price is expected to be negative. 
TABLE 4

Effect of a 10 Percent Reduction in Petroleum Prices on 2000 EBASEC

\begin{tabular}{|c|c|c|c|c|c|c|c|c|}
\hline State & $\begin{array}{c}\text { EBASEC, } \\
1999\end{array}$ & $\begin{array}{c}\text { EBASEC, } \\
2000\end{array}$ & $\begin{array}{l}\% \text { Growth } \\
1999-2000\end{array}$ & $\begin{array}{c}\text { Elasticity*10\% } \\
\text { Price Reduction } \\
\text { (From Table } 3 \text { ) }\end{array}$ & $\begin{array}{c}\text { Resulting } \\
\text { Effect on \%GR } \\
\text { of EBASEC }\end{array}$ & $\begin{array}{c}\text { Imputed } 2000 \\
\text { EBASEC } \\
\text { Level }\end{array}$ & $\begin{array}{c}\text { Jobs } \\
\text { Saved }\end{array}$ & $\begin{array}{c}\% \text { of } \\
(1999) \\
\text { EBASEC }\end{array}$ \\
\hline $\mathrm{OH}$ & $396,377.00$ & $398,101.00$ & 0.43 & 0.92 & 1.36 & $401,793.41$ & $3,692.41$ & 0.93 \\
\hline $\mathrm{TN}$ & $277,696.00$ & $280,398.00$ & 0.97 & 0.92 & 1.89 & $282,998.71$ & $2,600.71$ & 0.94 \\
\hline IN & $254,330.00$ & $251,483.00$ & -1.13 & 0.92 & -0.20 & $253,815.52$ & $2,332.52$ & 0.92 \\
\hline $\mathrm{NC}$ & $407,947.00$ & $395,844.00$ & -3.01 & 0.58 & -2.43 & $398,153.00$ & $2,309.00$ & 0.57 \\
\hline GA & $313,607.00$ & $314,346.00$ & 0.24 & 0.58 & 0.82 & $316,179.61$ & $1,833.61$ & 0.58 \\
\hline WI & $239,094.00$ & $238,079.00$ & -0.43 & 0.58 & 0.16 & $239,467.74$ & $1,388.74$ & 0.58 \\
\hline MI & $151,220.00$ & $148,225.00$ & -2.00 & 0.92 & -1.08 & $149,599.79$ & $1,374.79$ & 0.91 \\
\hline OR & $122,425.00$ & $122,041.00$ & -0.31 & 0.92 & 0.61 & $123,172.94$ & $1,131.94$ & 0.92 \\
\hline $\mathrm{SC}$ & $181,268.00$ & $176,046.00$ & -2.92 & 0.58 & -2.34 & $177,072.90$ & $1,026.90$ & 0.57 \\
\hline IA & $98,834.00$ & $81,161.00$ & -19.70 & 0.92 & -18.78 & $81,913.77$ & 752.77 & 0.76 \\
\hline $\mathrm{MN}$ & $127,895.00$ & $128,548.00$ & 0.51 & 0.58 & 1.09 & $129,297.83$ & 749.83 & 0.59 \\
\hline NY & $326,561.00$ & $331,595.00$ & 1.53 & 0.21 & 1.74 & $332,305.27$ & 710.27 & 0.22 \\
\hline WV & $75,906.00$ & $75,515.00$ & -0.52 & 0.92 & 0.41 & $76,215.41$ & 700.41 & 0.92 \\
\hline $\mathrm{CA}$ & $435,808.00$ & $442,114.00$ & 1.44 & 0.16 & 1.59 & $442,813.68$ & 699.68 & 0.16 \\
\hline NJ & $308,194.00$ & $319,670.00$ & 3.66 & 0.16 & 3.81 & $320,175.90$ & 505.90 & 0.16 \\
\hline UT & $78,596.00$ & $79,948.00$ & 1.71 & 0.58 & 2.29 & $80,414.35$ & 466.35 & 0.59 \\
\hline $\mathrm{AZ}$ & $77,788.00$ & $79,933.00$ & 2.72 & 0.58 & 3.30 & $80,399.26$ & 466.26 & 0.60 \\
\hline VA & $137,087.00$ & $133,532.00$ & -2.63 & 0.21 & -2.41 & $133,818.02$ & 286.02 & 0.21 \\
\hline $\mathrm{FL}$ & $172,474.00$ & $172,919.00$ & 0.26 & 0.16 & 0.42 & $173,192.66$ & 273.66 & 0.16 \\
\hline WA & $109,045.00$ & $107,667.00$ & -1.27 & 0.21 & -1.06 & $107,897.62$ & 230.62 & 0.21 \\
\hline
\end{tabular}




\begin{tabular}{|c|c|c|c|c|c|c|c|c|}
\hline State & $\begin{array}{c}\text { EBASEC } \\
1999 \\
\end{array}$ & $\begin{array}{c}\text { EBASEC, } \\
2000 \\
\end{array}$ & $\begin{array}{l}\text { \% Growth } \\
1999-2000 \\
\end{array}$ & $\begin{array}{l}\text { Elasticity* } 10 \% \\
\text { Price Reduction } \\
\text { (From Table } 3 \text { ) }\end{array}$ & $\begin{array}{c}\text { Resulting } \\
\text { Effect on \%GR } \\
\text { of EBASEC } \\
\end{array}$ & $\begin{array}{c}\text { Imputed } 2000 \\
\text { EBASEC } \\
\text { Level } \\
\end{array}$ & $\begin{array}{c}\text { Jobs } \\
\text { Saved } \\
\end{array}$ & $\begin{array}{c}\% \text { of } \\
(1999) \\
\text { EBASEC }\end{array}$ \\
\hline MS & $105,935.00$ & $104,112.00$ & -1.74 & 0.21 & -1.52 & $104,335.01$ & 223.01 & 0.21 \\
\hline ID & $37,730.00$ & $37,377.00$ & -0.94 & 0.58 & -0.36 & $37,595.02$ & 218.02 & 0.58 \\
\hline LA & $117,933.00$ & $117,388.00$ & -0.46 & 0.18 & -0.28 & $117,604.58$ & 216.58 & 0.18 \\
\hline OK & $98,702.00$ & $102,533.00$ & 3.81 & 0.18 & 3.99 & $102,722.17$ & 189.17 & 0.19 \\
\hline $\mathrm{CT}$ & $66,445.00$ & $67,513.00$ & 1.59 & 0.21 & 1.81 & $67,657.61$ & 144.61 & 0.22 \\
\hline $\mathrm{KS}$ & $71,097.00$ & $72,031.00$ & 1.31 & 0.18 & 1.49 & $72,163.89$ & 132.89 & 0.19 \\
\hline SD & $20,058.00$ & $20,086.00$ & 0.14 & 0.58 & 0.72 & $20,203.16$ & 117.16 & 0.58 \\
\hline $\mathrm{CO}$ & $59,146.00$ & $61,209.00$ & 3.43 & 0.18 & 3.61 & $61,321.93$ & 112.93 & 0.19 \\
\hline MD & $42,529.00$ & $47,017.00$ & 10.03 & 0.21 & 10.25 & $47,117.71$ & 100.71 & 0.24 \\
\hline $\mathrm{NE}$ & $46,523.00$ & $48,798.00$ & 4.77 & 0.16 & 4.93 & $48,875.23$ & 77.23 & 0.17 \\
\hline MT & $31,726.00$ & $28,690.00$ & -10.06 & 0.21 & -9.84 & $28,751.45$ & 61.45 & 0.19 \\
\hline $\mathrm{ME}$ & $36,612.00$ & $36,871.00$ & 0.70 & 0.16 & 0.86 & $36,929.35$ & 58.35 & 0.16 \\
\hline HI & $33,233.00$ & $34,667.00$ & 4.22 & 0.16 & 4.38 & $34,721.86$ & 54.86 & 0.17 \\
\hline NV & $40,722.00$ & $41,713.00$ & 2.40 & 0.13 & 2.53 & $41,766.88$ & 53.88 & 0.13 \\
\hline DE & $29,920.00$ & $30,214.00$ & 0.98 & 0.13 & 1.11 & $30,253.02$ & 39.02 & 0.13 \\
\hline $\mathrm{AK}$ & $19,737.00$ & $20,063.00$ & 1.64 & 0.18 & 1.82 & $20,100.02$ & 37.02 & 0.19 \\
\hline ND & $19,000.00$ & $19,253.00$ & 1.32 & 0.18 & 1.51 & $19,288.52$ & 35.52 & 0.19 \\
\hline WY & $17,965.00$ & $17,764.00$ & -1.13 & 0.18 & -0.94 & $17,796.77$ & 32.77 & 0.18 \\
\hline NM & $22,228.00$ & $19,936.00$ & -10.88 & 0.16 & -10.72 & $19,967.55$ & 31.55 & 0.14 \\
\hline $\mathrm{NH}$ & $22,916.00$ & $22,908.00$ & -0.03 & 0.13 & 0.09 & $22,937.59$ & 29.59 & 0.13 \\
\hline RI & $13,364.00$ & $17,745.00$ & 28.35 & 0.13 & 28.48 & $17,767.92$ & 22.92 & 0.17 \\
\hline VT & $8,437.00$ & $8,766.00$ & 3.83 & 0.13 & 3.95 & $8,777.32$ & 11.32 & 0.13 \\
\hline
\end{tabular}




\section{THE IMPACT OF A GAS TAX SUSPENSION AND THE ECONOMICS AND POLITICS OF SUCH A POLICY}

\subsection{The Impact of a Gas Tax Suspension}

The preceding analysis measured a ceteris paribus impact on employment growth from a 10 percent decrease in petroleum prices. Given the recent surge in gas prices and some states either adopting or considering a temporary suspension of gas tax collections, we now use our model to simulate the possible impact on energy employment in a state from such an action. Columns 2 and 3 in Table 5 report data on each state's imposed gas tax as well as the average price (including state and federal gas taxes) for regular unleaded gasoline in the year 2000, respectively. The fourth column reports the percent of the full gas price attributable to the state gas tax. Applying (the negative of) this percentage to the estimated price elasticities reported in Table 3, we can get a rough measure of the impact a petroleum price reduction equivalent to a gas tax suspension on a state's energy intensive employment growth (column 5, Table 5). ${ }^{22}$

Suppose, then, that each state realized such a price change in 2000. We then ask the counterfactual question: what would have been the impact on energy (consumption) base employment in each state? Recall that in Table 4 we reported the actual 1999 and 2000 energy intensive basic employment levels for each state as well as the growth rate over that period. Using the estimated impact on energy (consumption) employment growth (column 5, Table 5), we can estimate what energy consuming base employment would have been in 2000 had the gas tax been suspended. Column 7 of Table 5 presents this imputed 2000 employment level, and column 8 reports the difference between this and the actual 2000 employment level ranked according to states that stand to gain the most from a price reduction. In terms of jobs saved, the top five gaining states are Pennsylvania (saving 6,327 jobs), Ohio (saving 5,508 jobs), Tennessee (saving 3,793 jobs), North Carolina (saving 3,660 jobs), and Alabama (saving 2,657 jobs). Other states that gain jobs measured in the thousands of employees from a state gas tax suspension include Indiana, Illinois, Wisconsin, and Michigan, all of whom are largely industrial, net energy consuming states. States that appear to be relatively insulated from petroleum product prices and thus unlikely to enjoy appreciable employment gains from a tax suspension are Vermont, Alaska, Wyoming, and New Hampshire. This is not too surprising since according to the data, these are all states with a relatively few number of jobs that are energy consuming in nature.

\footnotetext{
${ }^{22}$ Again, implicit in this estimate is the assumption that there is a strong correlation between the price of petroleum products used to estimate the elasticities presented in Table 3 and regular unleaded gasoline prices. Since the correlations between motor gas prices and petroleum prices more broadly defined is so high (see footnote 17), such an assumption is not too unreasonable.
} 
TABLE 5

Potential Impact of a State Tax Suspension on EBASEC

\begin{tabular}{|c|c|c|c|c|c|c|c|c|}
\hline State & $\begin{array}{l}\text { State Gas Tax } \\
\text { (cents per } \\
\text { gallon) } 1\end{array}$ & $\begin{array}{l}\text { Gas Price } \\
\text { (Incl. Taxes) } \\
\text { (cents per } \\
\text { gallon) }^{1,2}\end{array}$ & $\begin{array}{l}\text { State Tax } \\
\% \text { of Full } \\
\text { Price }\end{array}$ & $\begin{array}{c}\text { Elasticity*\%Price } \\
\text { Reduction } \\
\text { (from Table } 3 \text { ) }\end{array}$ & $\begin{array}{l}\text { Resulting } \\
\text { Effect on } \\
\% \text { GR of } \\
\text { EBASEC }\end{array}$ & $\begin{array}{l}\text { Imputed } \\
2000 \\
\text { EBASEC } \\
\text { Level }\end{array}$ & $\begin{array}{c}\text { Jobs Saved } \\
\text { (est.) }\end{array}$ & $\begin{array}{c}\% \text { of } \\
(1999) \\
\text { EBASEC }\end{array}$ \\
\hline PA & 25.90 & 147.40 & 17.57 & 1.62 & 4.79 & $393,213.36$ & $6,327.36$ & 1.69 \\
\hline $\mathrm{OH}$ & 22.00 & 147.80 & 14.88 & 1.37 & 1.81 & $403,609.57$ & $5,508.57$ & 1.39 \\
\hline $\mathrm{TN}$ & 20.00 & 137.40 & 14.56 & 1.34 & 2.31 & $284,191.58$ & $3,793.58$ & 1.37 \\
\hline $\mathrm{NC}$ & 22.30 & 140.90 & 15.83 & 0.92 & -2.09 & $399,504.62$ & $3,660.62$ & 0.90 \\
\hline $\mathrm{AL}$ & 18.00 & 138.10 & 13.03 & 1.20 & -0.20 & $222,133.00$ & $2,657.00$ & 1.19 \\
\hline IN & 15.00 & 140.30 & 10.69 & 0.99 & -0.14 & $253,977.58$ & $2,494.58$ & 0.98 \\
\hline IL & 19.00 & 149.70 & 12.69 & 0.74 & 1.28 & $320,555.60$ & $2,357.60$ & 0.74 \\
\hline WI & 23.80 & 150.90 & 15.77 & 0.92 & 0.49 & $240,273.01$ & $2,194.01$ & 0.92 \\
\hline MI & 19.00 & 145.80 & 13.03 & 1.20 & -0.80 & $150,019.08$ & $1,794.08$ & 1.19 \\
\hline OR & 24.00 & 160.70 & 14.93 & 1.38 & 1.06 & $123,735.37$ & $1,694.37$ & 1.38 \\
\hline $\mathrm{SC}$ & 16.00 & 134.20 & 11.92 & 0.69 & -2.23 & $177,271.00$ & $1,225.00$ & 0.68 \\
\hline WV & 25.35 & 149.25 & 16.98 & 1.57 & 1.05 & $76,708.48$ & $1,193.48$ & 1.57 \\
\hline MO & 17.00 & 139.70 & 12.17 & 0.71 & 0.06 & $167,938.41$ & $1,184.41$ & 0.71 \\
\hline KY & 16.40 & 141.20 & 11.61 & 0.68 & 1.55 & $169,493.12$ & $1,141.12$ & 0.68 \\
\hline $\mathrm{TX}$ & 20.00 & 137.50 & 14.55 & 0.27 & 2.02 & $414,985.13$ & $1,111.13$ & 0.27 \\
\hline GA & 7.50 & 125.00 & 6.00 & 0.35 & 0.58 & $315,444.89$ & $1,098.89$ & 0.35 \\
\hline NY & 22.65 & 150.15 & 15.08 & 0.32 & 1.85 & $332,667.02$ & $1,072.02$ & 0.33 \\
\hline IA & 20.00 & 144.70 & 13.82 & 1.28 & -18.42 & $82,203.30$ & $1,042.30$ & 1.05 \\
\hline AR & 18.60 & 137.30 & 13.55 & 0.79 & 0.39 & $130,843.89$ & $1,026.89$ & 0.79 \\
\hline $\mathrm{MN}$ & 20.00 & 151.30 & 13.22 & 0.77 & 1.28 & $129,540.12$ & 992.12 & 0.78 \\
\hline $\mathrm{CA}$ & 18.00 & 151.90 & 11.85 & 0.19 & 1.62 & $442,943.24$ & 829.24 & 0.19 \\
\hline UT & 24.50 & 148.90 & 16.45 & 0.96 & 2.66 & $80,716.77$ & 768.77 & 0.98 \\
\hline $\mathrm{AZ}$ & 18.00 & 147.80 & 12.18 & 0.71 & 3.43 & $80,501.20$ & 568.20 & 0.73 \\
\hline $\mathrm{NJ}$ & 10.50 & 141.70 & 7.41 & 0.12 & 3.77 & $320,044.80$ & 374.80 & 0.12 \\
\hline VA & 17.50 & 140.20 & 12.48 & 0.27 & -2.36 & $133,889.12$ & 357.12 & 0.26 \\
\hline ID & 25.00 & 156.00 & 16.03 & 0.93 & -0.01 & $37,727.01$ & 350.01 & 0.93 \\
\hline
\end{tabular}




\begin{tabular}{|c|c|c|c|c|c|c|c|c|}
\hline State & $\begin{array}{l}\text { State Gas Tax } \\
\text { (cents per } \\
\text { gallon) })^{1} \\
\end{array}$ & $\begin{array}{l}\text { Gas Price } \\
\text { (Incl. Taxes) } \\
\text { (cents per } \\
\text { gallon) }\end{array}$ & $\begin{array}{c}\text { State Tax } \\
\% \text { of Full } \\
\text { Price } \\
\end{array}$ & $\begin{array}{c}\text { Elasticity*\%Price } \\
\text { Reduction } \\
\text { (from Table 3) }\end{array}$ & $\begin{array}{l}\text { Resulting } \\
\text { Effect on } \\
\% \text { GR of } \\
\text { EBASEC }\end{array}$ & $\begin{array}{l}\text { Imputed } \\
2000 \\
\text { EBASEC } \\
\text { Level } \\
\end{array}$ & $\begin{array}{c}\text { Jobs Saved } \\
\text { (est.) }\end{array}$ & $\begin{array}{c}\% \text { of } \\
(1999) \\
\text { EBASEC }\end{array}$ \\
\hline WA & 23.00 & 156.70 & 14.68 & 0.31 & -0.96 & $108,005.67$ & 338.67 & 0.31 \\
\hline LA & 20.00 & 139.10 & 14.38 & 0.27 & -0.20 & $117,699.52$ & 311.52 & 0.26 \\
\hline MA & 21.00 & 154.10 & 13.63 & 0.29 & 0.29 & $106,971.46$ & 311.46 & 0.29 \\
\hline $\mathrm{CT}$ & 36.00 & 167.70 & 21.47 & 0.46 & 2.05 & $67,823.82$ & 310.82 & 0.47 \\
\hline MS & 18.40 & 141.60 & 12.99 & 0.28 & -1.46 & $104,401.88$ & 289.88 & 0.27 \\
\hline FL & 13.00 & 132.20 & 9.83 & 0.16 & 0.41 & $173,188.10$ & 269.10 & 0.16 \\
\hline OK & 17.00 & 136.00 & 12.50 & 0.23 & 4.04 & $102,769.52$ & 236.52 & 0.24 \\
\hline KS & 18.00 & 138.90 & 12.96 & 0.24 & 1.54 & $72,203.26$ & 172.26 & 0.24 \\
\hline $\mathrm{CO}$ & 22.00 & 148.70 & 14.79 & 0.27 & 3.70 & $61,376.15$ & 167.15 & 0.28 \\
\hline MD & 23.50 & 146.00 & 16.10 & 0.34 & 10.38 & $47,179.21$ & 162.21 & 0.38 \\
\hline SD & 20.00 & 152.70 & 13.10 & 0.76 & 0.90 & $20,239.59$ & 153.59 & 0.77 \\
\hline $\mathrm{NE}$ & 24.60 & 149.10 & 16.50 & 0.26 & 5.04 & $48,925.48$ & 127.48 & 0.27 \\
\hline MT & 27.00 & 158.70 & 17.01 & 0.36 & -9.69 & $28,794.63$ & 104.63 & 0.33 \\
\hline NV & 24.75 & 164.85 & 15.01 & 0.19 & 2.60 & $41,793.91$ & 80.91 & 0.20 \\
\hline $\mathrm{ME}$ & 19.00 & 149.00 & 12.75 & 0.20 & 0.91 & $36,945.42$ & 74.42 & 0.20 \\
\hline $\mathrm{DE}$ & 23.00 & 149.90 & 15.34 & 0.20 & 1.18 & $30,273.90$ & 59.90 & 0.20 \\
\hline HI & 16.00 & 163.30 & 9.80 & 0.15 & 4.38 & $34,720.75$ & 53.75 & 0.16 \\
\hline ND & 20.00 & 152.00 & 13.16 & 0.24 & 1.57 & $19,299.75$ & 46.75 & 0.25 \\
\hline RI & 29.00 & 156.50 & 18.53 & 0.24 & 28.59 & $17,787.49$ & 42.49 & 0.32 \\
\hline NM & 18.88 & 147.18 & 12.82 & 0.20 & -10.68 & $19,976.47$ & 40.47 & 0.18 \\
\hline $\mathrm{NH}$ & 19.50 & 151.50 & 12.87 & 0.17 & 0.13 & $22,946.09$ & 38.09 & 0.17 \\
\hline WY & 9.00 & 139.50 & 6.45 & 0.12 & -1.01 & $17,785.14$ & 21.14 & 0.12 \\
\hline $\mathrm{AK}$ & 8.00 & 157.80 & 5.07 & 0.09 & 1.73 & $20,081.76$ & 18.76 & 0.10 \\
\hline VT & 20.00 & 151.00 & 13.25 & 0.17 & 4.00 & $8,781.00$ & 15.00 & 0.18 \\
\hline
\end{tabular}


While it is useful to envision level changes in employment, working with levels can be misleading, particularly for highly populated states like Texas and Ohio. ${ }^{23}$ Viewing these job gains as a percent of 1999 energy intensive, consuming base employment, the top five gaining states are Pennsylvania (gaining 1.69 percent), West Virginia (gaining 1.57 percent), Ohio (gaining 1.39 percent), Oregon (gaining 1.38 percent), and Tennessee (gaining 1.37 percent). Other states making relatively large gains include, not surprisingly, Michigan, Iowa, and Indiana. It is somewhat interesting that Illinois does not appear to be a major beneficiary of a tax suspension policy even though they were one of the few states to suspend gas taxes in 2000. When looking at these percentages, Alaska and Wyoming are again states that gain the least from a gas tax suspension. Moreover, it is worth noting that while more populated states like Florida and New Jersey would stand to gain 270 and 375 employees, respectively, from a gas tax suspension, when viewed in percentage terms, these gains are extremely small. For New Jersey, for instance, these 375 jobs represent about 0.12 percent of the total energy consuming employment base.

Clearly, then, the overall effect of a tax suspension will likely be small. Indeed, for reasons indicated above, as our estimated elasticities in all likelihood represent an upper bound on the magnitude of a price effect on energy-consuming employment growth, the above estimates provide the best possible employment impact of a gas tax suspension for a state, and that impact is rather small.

\subsection{A Simplified Benefit/Cost Analysis of a Gas Tax Suspension}

Even though job gains are rather slight, the question remains as to whether these employment increases, and their associated benefits, exceed the cost of lost public revenues. In this section we undertake a quick benefit-cost analysis of the efficacy of such a tax suspension with respect to the particular case of Indiana, a state which actually did suspend its gasoline tax collection. We focus particular attention on employment gains as the benefit and tax revenue foregone as the cost. ${ }^{24}$

${ }^{23}$ It should be noted that working with percentages can be somewhat misleading as well particularly if one is considering a state that has a relatively small employment base to begin with.

${ }^{24}$ To be sure, our measure of jobs gained as the benefit of a tax is quite narrow. Clearly a tax suspension may have other benefits. For instance, the suspension of a gas tax would likely increase consumer surplus in the gas market, thereby increasing disposable income for a state's residences. The potential for increased spending on items other than gasoline would then represent a benefit to consumers that may show up in higher gross state product (GSP) numbers. Indeed, a useful research extension would be to measure to what extent petroleum product prices impact GSP growth. By construction, our analysis is restricted to employment effects and therefore cannot speak to a broader benefit. However, we do believe that it is nonetheless very important to view employment effects as a major benefit of such a tax policy. The success or failure of many fiscal policies, whether national, regional, or state-level in nature, is often measured by their ability to create and sustain jobs. New (or saved) jobs generate income that benefits both a state's markets and fiscal health. So while not a complete measure of benefit, employment gains do represent a significant piece of the total benefit measure. 
To reiterate, it seems reasonable to conclude, based on the estimates presented above, that suspension of a gas tax is likely to have a negligible effect on a state's overall economy. Even a state such as Ohio where energy intensive (and primarily energy consuming) jobs account for 32 percent of its employment base, the number of jobs saved on a percentage basis is rather small. Since the employment benefits of a tax suspension seem small and its potential costs, in the form of reduced revenues necessary to fund road and other state infrastructure products, can be rather high, we might conclude such a policy to be flawed. In fact, these results suggest that in order to counter budget shortfalls, rather than cutting vital public services, a temporary gas tax increase might be a reasonable policy to consider, political considerations aside.

Indeed, consider Indiana. As stated earlier, suspension of the gas tax is reported to have cost the state some $\$ 22$ million in lost revenue collections over a 60 -day period. According to our analysis, the total number of jobs saved is on the order of 2,495 . If the average worker in the energy intensive industries in question earns, say, $\$ 60,000$ per year and, as reported by Federation of Tax Administrators, Indiana's (flat) income tax rate is 3.4 percent, then saving these jobs could retain some $\$ 5.1$ million in income tax revenue. ${ }^{25}$ Further, if each worker were to spend 75 percent of his remaining income on state taxable goods and services, assuming a sales tax of 6 percent, tax revenues would increase to about $\$ 11.6$ million. To be sure, this $\$ 11.6$ million figure does not reflect the savings in the form of unemployment compensation support that the state would otherwise have had to provide nor any feedback effects these saved jobs would have had on the rest of the state's economy. Nonetheless, reaching total benefits of suspended tax relief necessary to cover the estimated $\$ 22$ million cost may be difficult to attain. Thus, while it is unreasonable to suggest that our analysis here is an indictment of a state gas tax suspension, it does highlight the need for precise measurement to determine whether such a policy is economically justified.

\section{CONCLUSION}

In this paper we have investigated the likely impact of reduced petroleum product prices on U.S. states' economies. By decomposing state employment into basic versus non-basic industries and further subdividing basic industries into energy intensive versus non-energy intensive industries, we find that the petroleum price elasticity on energy intensive employment growth can range from -8.09 percent for those primarily energy consuming states to 5.29 percent for those primarily energy producing states. However, we want to emphasize that our findings are positive in nature. It is not our objective to address normative issues such as tax fairness or market distortions.

Focusing attention on policy aimed at suspending state gasoline taxes as a way to bolster the economy in periods of high energy prices and lackluster employment growth, our analysis suggests that while such a suspension will have a beneficial effect on job

${ }^{25}$ See www.taxadmin.org 
growth in each state, the impact varies from state to state. Moreover, even for those states that gain the most jobs relative to other states, the gains are very small, calling into question the efficacy of such a policy.

There are several avenues of future research that would be beneficial to explore. First, the focus in this paper has been on employment. However, employment decisions by firms may not be as quick to respond to changes in energy prices as other inputs to production. It might be beneficial to explore energy intensive base industries' responses to energy prices using real gross state product or personal income rather than employment. Secondly, while economic base theory has some reasonably strong empirical support, it does not allow us to understand the inter-linkages between industries (either within or outside the economic base) that, say, an input-output or regional computable general equilibrium model might provide. ${ }^{26}$

Since 2000, gas prices have for the most part managed to remain high; and given today's uncertain political environment, there is no immediate reason to believe that the price levels we enjoyed in the 1990s will return any time soon. Irrespective of the type of economic methodology employed, it is clear, perhaps now more than ever, that we need to further develop our understanding of the linkages between energy prices and the local economy. While a great deal of interesting and reliable work has been done to understand these linkages at the national level, more work must be undertaken at the regional level if effective local policies are to be adopted to combat high energy prices.

\section{REFERENCES}

Adhicary, D., 2000. "Illinois Governor Suspends State Gas Tax to Ease Fuel Price Spike," available at www.cnn.com/2000/ALLPOLITICS/stories/06/28/gas.prices/ June 28.

Aksamit, N., 2002. "Gas-Tax Hike Down the Road," The Omaha World Herald, Thursday, October 31.

Armstrong, H. and J. Taylor, 2000. Regional Economics and Policy, Third Ediiton. Blackwell Publishers, Inc.

Bohi, D.R. and J.R. Powers, 1993. "Energy Price Shocks and Regional Output and Employment," The Review of Regional Studies 23, 129-142.

Brown, S.P.A. and J.K. Hill, 1988. "Lower Oil Prices and State Employment," Contemporary Policy Issues 4(3), 60-68.

Brown, S.P.A. and J.K. Hill, 1995. "Energy Prices and State Economic Performance," Federal Reserve Bank of Dallas, Second Quarter, 13-23.

Deravi, K. and C. Hegji, 1992. "The Inflationary Impact of Oil Price Shocks: A Vector Autoregressive Study," Review of Financial Economics 2(1), 1-16.

Hamilton, J.D., 1983. "Oil and the Macroeconomy Since World War II," Journal of Political Economy 91(2), 228-48.

${ }^{26}$ Although it should be noted that such models, while valuable in their own right, do suffer from data limitations that the model structure employed here does not. 
Hoag, J.H. and M. Wheeler, 1996. "Oil Price Shocks and Employment: The Case of Ohio Coal Mining," Energy Economics 18, 211-220.

Hunt, G.L., 1988. "The Impact of Oil Price Fluctuations on the Economies of Energy Producing States," Review of Regional Studies 18, 60-78.

Indianapolis Star, 2000. "Governor Suspends Gas Tax," taken from Indystar.com at www.indystart.com.

Munnell, A.H., 1990. "How Does Public Infrastructure Affect Regional Economic Performance?" New England Economic Review Sept/Oct., 10-32.

Polzin, P.E., 2001. "Why Some States Grow Faster than Others: New Growth Models for State Economic Policy," Growth and Change 32(2), 413-425.

Stern, D.I., 1993. "Energy and Economic Growth in the USA," Energy Economics 15, 137-150.

U.S. Department of Commerce. Bureau of Economic Analysis, 1995. BEA Regional Projections to 2045: Vol. 1, States. U.S. Government Printing Office: Washington D.C.

U.S. Department of Energy, Energy Information Administration, available at www.eia. doe.gov. 